\title{
CONTAMINATION OF HEAVY METALS IN SOIL OF MANDIDEEP INDUSTRIAL AREA, MADHYA PRADESH, INDIA
}

\author{
Reeta Kori \\ Central Laboratory, \\ Madhya Pradesh Pollution Control Board, \\ Paryavaran Parisar, \\ E-5, Arera Colony, \\ Bhopal, India
}

\section{Harish Wankhade}

Central Laboratory,

Madhya Pradesh Pollution Control Board,

Paryavaran Parisar,

E-5, Arera Colony,

Bhopal, India

\section{Ankita Kulshreshtha*}

Central Laboratory, Madhya Pradesh Pollution Control Board,

Paryavaran Parisar,

E-5, Arera Colony,

Bhopal, India

\author{
Alok Saxena \\ Central Laboratory, \\ Madhya Pradesh Pollution Control Board, \\ Paryavaran Parisar, \\ E-5, Arera Colony, \\ Bhopal, India
}

\author{
Asad Baig \\ Central Laboratory, \\ Madhya Pradesh Pollution Control Board, \\ Paryavaran Parisar, \\ E-5, Arera Colony, \\ Bhopal, India \\ Saket Mishra \\ Central Laboratory, \\ Madhya Pradesh Pollution Control Board, \\ Paryavaran Parisar, \\ E-5, Arera Colony, \\ Bhopal, India
}

\author{
Smriti Sen \\ Central Laboratory, \\ Madhya Pradesh Pollution Control Board, \\ Paryavaran Parisar, \\ E-5, Arera Colony, \\ Bhopal, India
}

Article DOI: https://doi.org/10.36713/epra5554

Corresponding Author

\section{ABSTRACT}

A study has been conducted to assess the heavy metal contamination in soil of Mandideep industrial area of Madhya Pradesh, India. Total twelve locations and one control location were selected in Mandideep industrial area for soil quality monitoring w.r.t. heavy metals. The thirteen soil samples were monitored for heavy metals such as Chromium (Cr), Manganese (Mn), Nickel (Ni), Copper (Cu), Zinc (Zn), Iron (Fe), Cadmium (Cd), Lead (Pb) and Cobalt (Co) analysis during different four quarters from April 2018 to March 2019. The present study is an attempt to visualize the heavy metal contamination with w.r.t. Contamination Index (CI), Pollution Load Index (PLI) study at selected locations in Mandideep industrial area. Over all Pollution Load Index of soil was found greater than one which shows polluted soil w.r.t. heavy metals at all selected monitoring locations in Mandideep industrial area of Madhya Pradesh, India during this study.

KEYWORDS: Industrial Area, Soil, Heavy Metals, Contamination Index (CI), Pollution Load Index (PLI) 


\section{INTRODUCTION}

Heavy metals are accumulated in soils mainly due to dry and wet atmospheric deposition from various sources; the main and most important origin of heavy metals is related to industrial emissions (chemistry, mining, iron and steel industry, metallurgy, building and electronics industry, etc.), fuel combustion, and waste management and transport (automobile traffic, a fuel composition, road types etc [1]. Heavy metals can be transferred into the human body as a consequence of dermal contact, inhalation, and ingestion [2-4]. Industrialization has been accompanied by increased concentrations of metals and semimetals in soils. Some, such as lead and cadmium, are non-essential, being potentially toxic even in very low concentrations; essential ones, such as copper, nickel, zinc, and manganese, are fundamental for many metabolic activities, but become toxic for concentrations above a certain threshold [5]. Due to rapid industrialization, excessive application of metals and synthetic chemicals in the terrestrial environment coupled with deficient environmental management has led to large scale pollution in the environment. Soils contaminated by heavy metals from human activities have raised serious concern in recent decades regarding potential risk to human health through the direct intake, bioaccumulation through food chain, and their impacts on ecological system [6,7]. Furthermore, exposure to the high amount of heavy metals can cause serious problems to human [8]. Heavy metals can be derived from both local and distant sources of emissions, and therefore can be deposited in situ or, due to their ability to be bound by dust, can be transported over long distances [9-11]. Most anthropogenic pollutants are emitted into the atmosphere and then are deposited on the soil surface [12]. Accumulation of metals may also be supported by natural processes. Vehicular pollution is also participates in heavy metal pollution of soil ecosystem. In addition to this, soil is also considered as the major sink for airborne metals. All aspects stated above become responsible for accumulation of heavy metals in the soil by one or way and thus give rise to soil pollution [13].Therefore pollution load index w.r.t. heavy metals in soil of Mandideep industrial area was observed in this study.

\section{METHODOLOGY}

\subsection{Study Area}

Mandideep is a municipality in Goharganj subdistrict of Raisen district in the Indian state of Madhya Pradesh. It is situated between the latitude $22^{\circ}$ $47^{\prime}$ and $23^{\circ} 33^{\prime}$ north and the longitude $77^{\circ} 21^{\prime}$ and $78^{\circ} 49^{\prime}$ east and is bounded in the west by Sehore District, in the north by Vidisha District, in the east and southeast by Sagar District, and in the south by Hoshangabad and Sehore districts.

\subsection{Monitoring Locations}

Total twelve locations and one control location in Mandideep industrial area were selected for soil monitoring w.r.t. heavy metals is depicted in table no 1 and figure no 1.

Table 1: Monitoring Locations at Mandideep Industrial Area

\begin{tabular}{|c|c|c|}
\hline S.N & Code & Monitoring Points \\
\hline 1 & S1 & Near M/S Bansal Extraction \& Exports Pvt, Ltd Mandideep \\
\hline 2 & S2 & Near M/S Bhaskar Industry, Mandideep \\
\hline 3 & S3 & Near M/S Proctor \& Gamble, Mandideep \\
\hline 4 & S4 & Near M/S Mahindra Steel Service Centre, Mandideep \\
\hline 5 & S5 & Near M/S Dawat Food Industry, Mandideep \\
\hline 6 & S6 & Near M/S HEG, Mandideep \\
\hline 7 & S7 & Near M/S Lupin ltd, Mandideep \\
\hline 8 & S8 & Near M/S Vardhman Yarns, Mandideep \\
\hline S & S9 & Near AKVN, Mandideep \\
\hline 10 & S10 & Near M/S Crompton \& Greaves, Mandideep \\
\hline 11 & S11 & Near St Chavara, H. S. School, New Satlapur Mandideep \\
\hline 12 & S12 & \\
\hline 13 & CS (Control Site) & \\
\hline
\end{tabular}




\section{EPRA International Journal of Multidisciplinary Research (IJMR) - Peer Reviewed Journal}

Volume: 6 | Issue: 11 |November 2020 || Journal DOI: 10.36713/epra2013 || SJIF Impact Factor: 7.032 ||ISI Value: 1.188

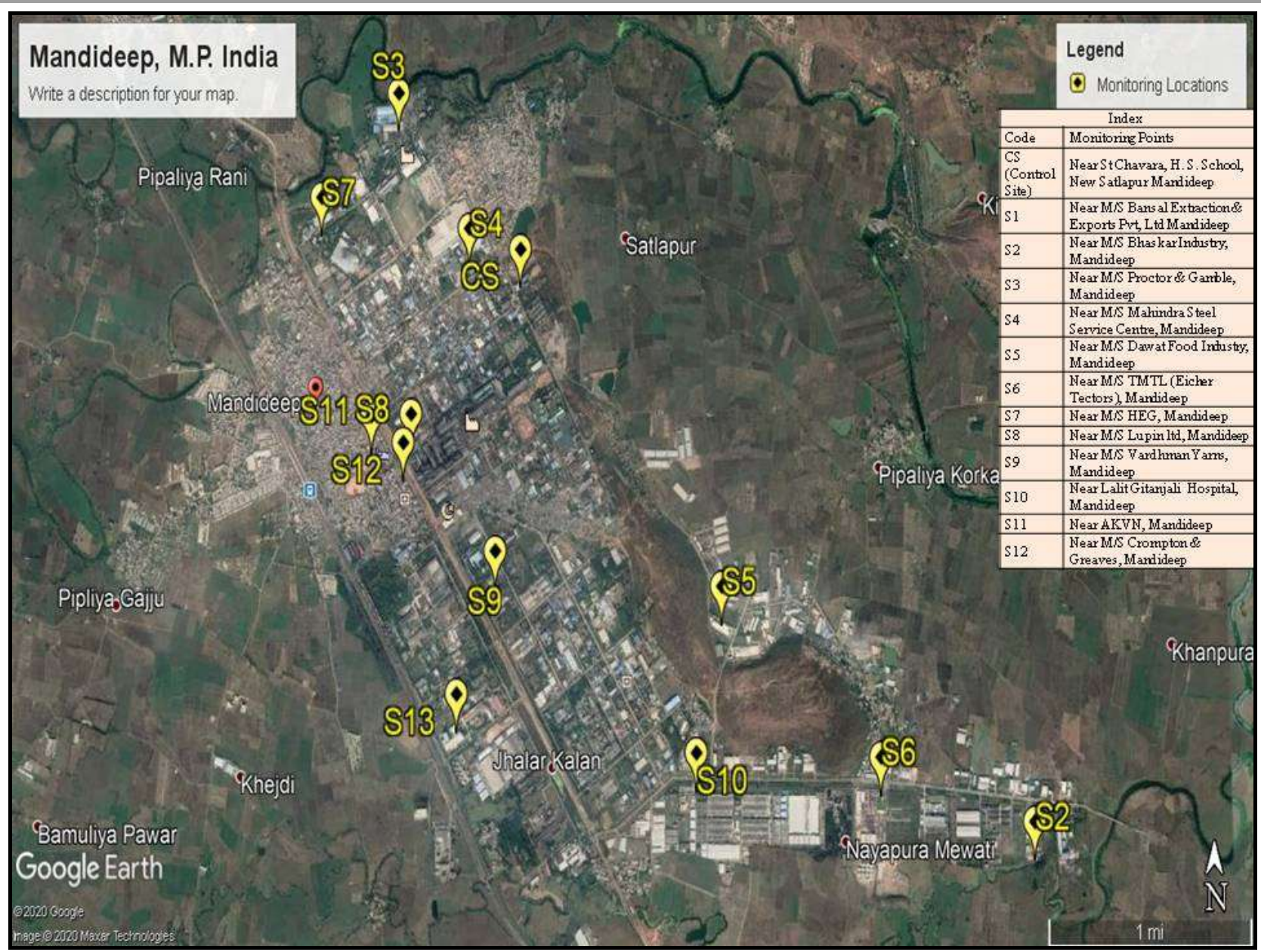

\subsection{Monitoring}

All soil monitoring was done as per standard guidelines followed by Central Pollution Control Board. The aliquots of soil mixed together (unwanted matters to be separated manually before mixing of samples) during collection from the each selected sampling area. Out of this mixture, approx. $500 \mathrm{gm}$ sample to be taken into polypropylene zip pouch, duly coded, labeled at field as per guidelines of Central Pollution Control Board. Soil samples were collected from the $05-15 \mathrm{~cm}$ depth, after removing surface contamination. Sampling was carried out using a plastic spatula and the use of metal tools was avoided. The samples were collected in self-locking polythene bags and were sealed in double bags.

\subsection{Digestion and Analysis}

Soil samples were dried for two days at room temperature. The dry soil sample was disaggregated with mortar and pestle. The sample was finely powdered to -250 mesh size (US Standard) using a swing grinding mill. All soil samples were digested by
Method $3050 B$ (Acid Dig

EPA Method 3050B (Acid Digestion of Sediments, Sludges And Soils) [14] and analyzed by atomic absorption spectrophotometer (Perkin Elmer Pinnacle 900H).

\subsection{Soil Pollution Indices}

Pollution assessment models are indicators used to assess the presence and intensity of anthropogenic contaminant deposition on soils. In this study, the following pollution assessment models were employed: Contamination Index (CI), Pollution Load Index (PLI) w.r.t heavy metals concentration present in soil.

\subsubsection{Contamination Index (CI)}

The contamination factors were derived by using the CI equation as defined [15]:

$\mathrm{CF}=\mathrm{Cn} / \mathrm{Bn}$.

Where $\mathrm{Cn}=$ measured metal concentration and $\mathrm{Bn}=$ background concentration from control site. The concentration factor observe as; $\mathrm{CF}<1$ low; $1<\mathrm{CF}<$ 
3 moderate; $3<\mathrm{CF}<6$ considerable, and $\mathrm{CF}>6$ as high contamination [16].

3.5.2. Pollution Load Index (PLI): The PLI gives a generalized assessment on the level of soil contamination. The PLI is obtained using approach as follows [17]:

$\mathrm{PLI}=[\mathrm{CF} 1 \times \mathrm{CF} 2 \times \mathrm{CF} 3 \times \ldots \ldots \times \mathrm{C} \mathrm{n}] 1 / \mathrm{n} \ldots \ldots(2)$ Where, $\mathrm{CF}=$ contamination factor; and $\mathrm{n}=$ number of metals. PLI $>1$ indicates pollution exists; PLI $<1$ indicates no metal pollution [18]; and PLI $=1$ indicates heavy metal loads close to the background level [19].

\section{RESULT \& DISCUSSIONS}

The observed concentration of heavy metals in soil is depicted in Table 2. Contamination index (CI) and Pollution load index (PLI) w.r.t. heavy metals in soil of all selected locations are presented in Table 3. All results are shown in figure no. 2 to figure no 11.

Table 2: Metals Concentration in Soil

\begin{tabular}{|c|c|c|c|c|c|c|c|c|c|}
\hline S.N. & $\begin{array}{c}\text { Heavy } \\
\text { Metals }\end{array}$ & Unit & CS & S1 & S2 & S3 & S4 & S5 & S6 \\
\hline 1 & $\mathrm{Cr}$ & $\mathrm{mg} / \mathrm{kg}$ & 17 & 29 & 22 & 21 & 22 & 25 & 20 \\
\hline 2 & $\mathrm{Mn}$ & $\mathrm{mg} / \mathrm{kg}$ & 195 & 346 & 249 & 245 & 210 & 316 & 231 \\
\hline 3 & $\mathrm{Ni}$ & $\mathrm{mg} / \mathrm{kg}$ & 22 & 27 & 23 & 30 & 25 & 26 & 27 \\
\hline 4 & $\mathrm{Cu}$ & $\mathrm{mg} / \mathrm{kg}$ & 28 & 37 & 266 & 65 & 68 & 58 & 38 \\
\hline 5 & $\mathrm{Zn}$ & $\mathrm{mg} / \mathrm{kg}$ & 56 & 93 & 76 & 75 & 67 & 78 & 72 \\
\hline 6 & $\mathrm{Co}$ & $\mathrm{mg} / \mathrm{kg}$ & 16 & 29 & 23 & 24 & 28 & 27 & 26 \\
\hline 7 & $\mathrm{Cd}$ & $\mathrm{mg} / \mathrm{kg}$ & 2 & 3 & 2 & 2 & 3 & 3 & 2 \\
\hline 8 & $\mathrm{Fe}$ & $\mathrm{mg} / \mathrm{kg}$ & 2077 & 11867 & 7235 & 11260 & 9928 & 10340 & 7154 \\
\hline 9 & $\mathrm{~Pb}$ & $\mathrm{mg} / \mathrm{kg}$ & 11 & 18 & 15 & 18 & 20 & 12 & 15 \\
\hline
\end{tabular}

\begin{tabular}{|c|c|c|c|c|c|c|c|c|}
\hline S.N. & $\begin{array}{c}\text { Heavy } \\
\text { Metals }\end{array}$ & Unit & S7 & S8 & S9 & S10 & S11 & S12 \\
\hline 1 & $\mathrm{Cr}$ & $\mathrm{mg} / \mathrm{kg}$ & 18 & 24 & 27 & 26 & 19 & 18 \\
\hline 2 & $\mathrm{Mn}$ & $\mathrm{mg} / \mathrm{kg}$ & 209 & 269 & 230 & 219 & 361 & 312 \\
\hline 3 & $\mathrm{Ni}$ & $\mathrm{mg} / \mathrm{kg}$ & 25 & 28 & 26 & 28 & 33 & 23 \\
\hline 4 & $\mathrm{Cu}$ & $\mathrm{mg} / \mathrm{kg}$ & 32 & 56 & 63 & 63 & 32 & 31 \\
\hline 5 & $\mathrm{Zn}$ & $\mathrm{mg} / \mathrm{kg}$ & 63 & 50 & 62 & 59 & 57 & 76 \\
\hline 6 & $\mathrm{Co}$ & $\mathrm{mg} / \mathrm{kg}$ & 27 & 26 & 26 & 24 & 24 & 23 \\
\hline 7 & $\mathrm{Cd}$ & $\mathrm{mg} / \mathrm{kg}$ & 2 & 3 & 2 & 2 & 3 & 8 \\
\hline 8 & $\mathrm{Fe}$ & $\mathrm{mg} / \mathrm{kg}$ & 11885 & 7549 & 10429 & 11901 & 9450 & 4994 \\
\hline 9 & $\mathrm{~Pb}$ & $\mathrm{mg} / \mathrm{kg}$ & 13 & 23 & 13 & 16 & 26 & 11 \\
\hline
\end{tabular}


EPRA International Journal of Multidisciplinary Research (IJMR) - Peer Reviewed Journal Volume: 6 | Issue: 11 |November 2020 || Journal DOI: 10.36713/epra2013 || SJIF Impact Factor: 7.032 ||ISI Value: 1.188

Table 3: Contamination index (CI) and Pollution load index (PLI) of Soil

\begin{tabular}{|c|c|c|c|c|c|c|c|c|c|c|c|c|}
\hline $\begin{array}{l}\text { Heavy } \\
\text { Metal }\end{array}$ & S1 & S2 & S3 & S4 & S5 & S6 & S7 & S8 & S9 & S10 & S11 & S12 \\
\hline $\mathrm{Cr}$ & 1.7 & 1.294 & 1.235 & 1.294 & 1.47 & 1.176 & 1.058 & 1.411 & 1.588 & 1.529 & 1.117 & 1.058 \\
\hline $\mathrm{Mn}$ & 1.774 & 1.276 & 1.256 & 1.076 & 1.62 & 1.184 & 1.071 & 1.379 & 1.179 & 1.123 & 1.851 & 1.6 \\
\hline $\mathrm{Ni}$ & 1.227 & 1.045 & 1.363 & 1.136 & 1.181 & 1.227 & 1.136 & 1.272 & 1.181 & 1.272 & 1.5 & 1.045 \\
\hline $\mathrm{Cu}$ & 1.321 & 9.5 & 2.321 & 2.428 & 2.071 & 1.357 & 1.142 & 2 & 2.25 & 2.25 & 1.142 & 1.107 \\
\hline $\mathrm{Zn}$ & 1.66 & 1.357 & 1.339 & 1.196 & 1.392 & 1.28 & 1.125 & 0.892 & 1.10 & 1.053 & 1.017 & 1.357 \\
\hline Co & 1.812 & 1.437 & 1.5 & 1.75 & 1.687 & 1.625 & 1.687 & 1.625 & 1.625 & 1.5 & 1.5 & 1.437 \\
\hline $\mathrm{Cd}$ & 1.5 & 1 & 1 & 1.5 & 1.5 & 1 & 1 & 1.5 & 1 & 1 & 1.5 & 4 \\
\hline $\mathrm{Fe}$ & 5.713 & 3.483 & 5.421 & 4.779 & 4.978 & 3.444 & 5.722 & 3.634 & 5.021 & 5.729 & 4.549 & 2.404 \\
\hline $\mathrm{Pb}$ & 1.636 & 1.363 & 1.636 & 1.818 & 1.09 & 1.363 & 1.181 & 2.09 & 1.181 & 1.454 & 2.363 & 1 \\
\hline PLI & 1.807 & 1.747 & 1.64 & 1.676 & 1.672 & 1.414 & 1.385 & 1.631 & 1.554 & 1.589 & 1.642 & 1.492 \\
\hline
\end{tabular}

Figure no 2 is showing that average concentration of Chromium (Cr) was found $17 \mathrm{mg} / \mathrm{kg}$ at control site (CS). Minimum average concentration was found 18
(S7 \& $\mathrm{S} 12) \quad \mathrm{mg} / \mathrm{kg}$ and maximum average concentration was found 29 (S1) $\mathrm{mg} / \mathrm{kg}$ during this study.

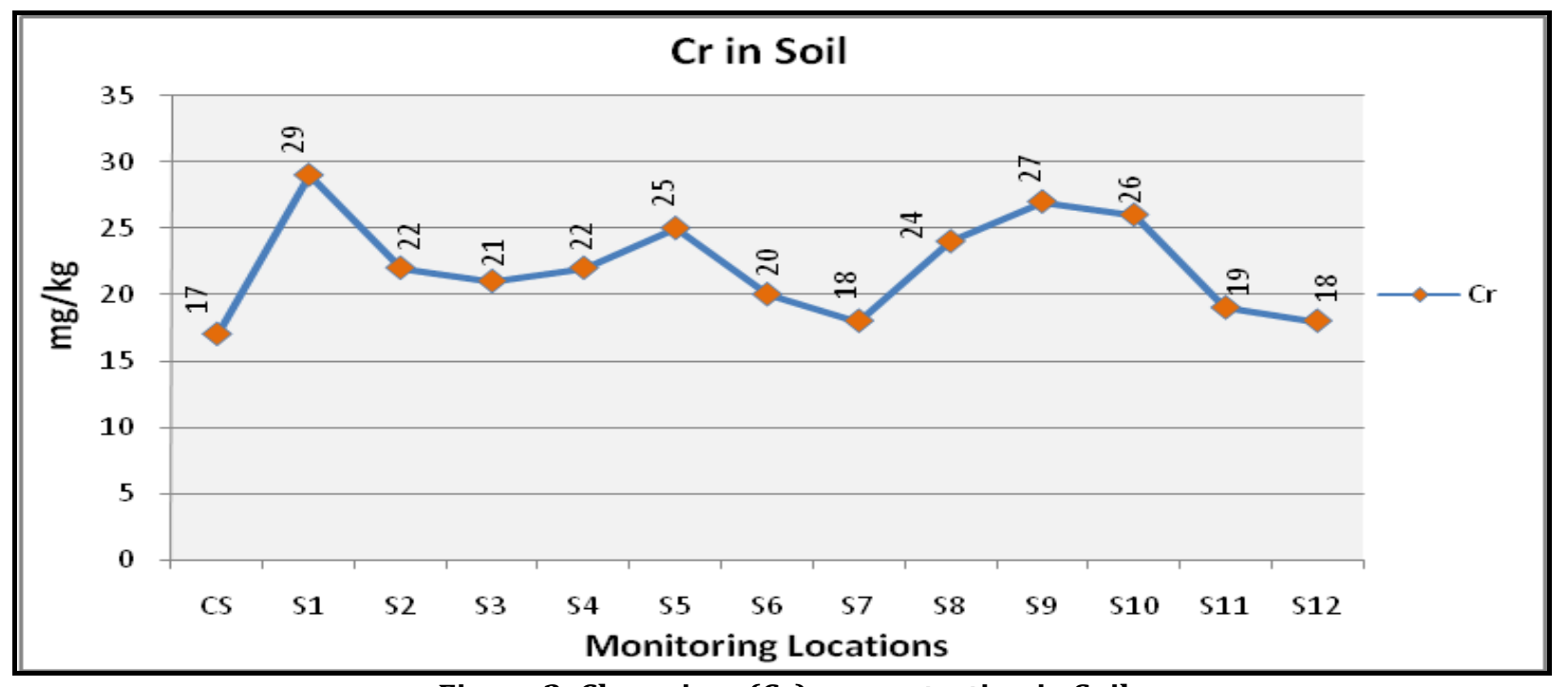

Figure 2: Chromium (Cr) concentration in Soil

Figure no 3 is showing that average concentration of Manganese (Mn) was found $195 \mathrm{mg} / \mathrm{kg}$ at control site (CS). Minimum average concentration was found 209
(S7) $\mathrm{mg} / \mathrm{kg}$ and maximum average concentration was found 361 (S11) $\mathrm{mg} / \mathrm{kg}$ during this study. 


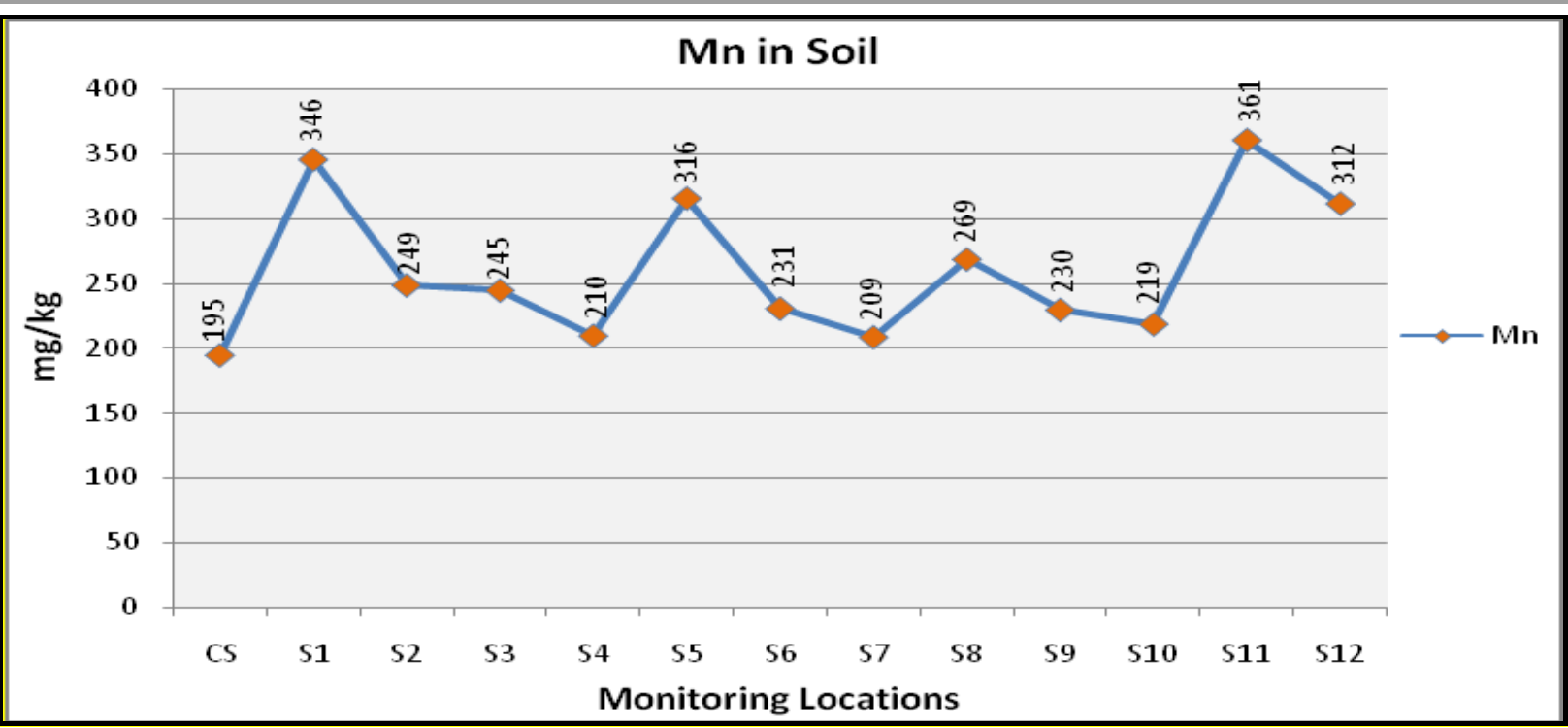

Figure 3: Manganese (Mn) concentration in Soil

Figure no 4 is showing that average concentration of Nickel (Ni) was found $22 \mathrm{mg} / \mathrm{kg}$ at control site (CS). Minimum average concentration was found 23 (S2 \&
$\mathrm{S} 12) \mathrm{mg} / \mathrm{kg}$ and maximum average concentration was found 33 (S11) $\mathrm{mg} / \mathrm{kg}$ during this study.

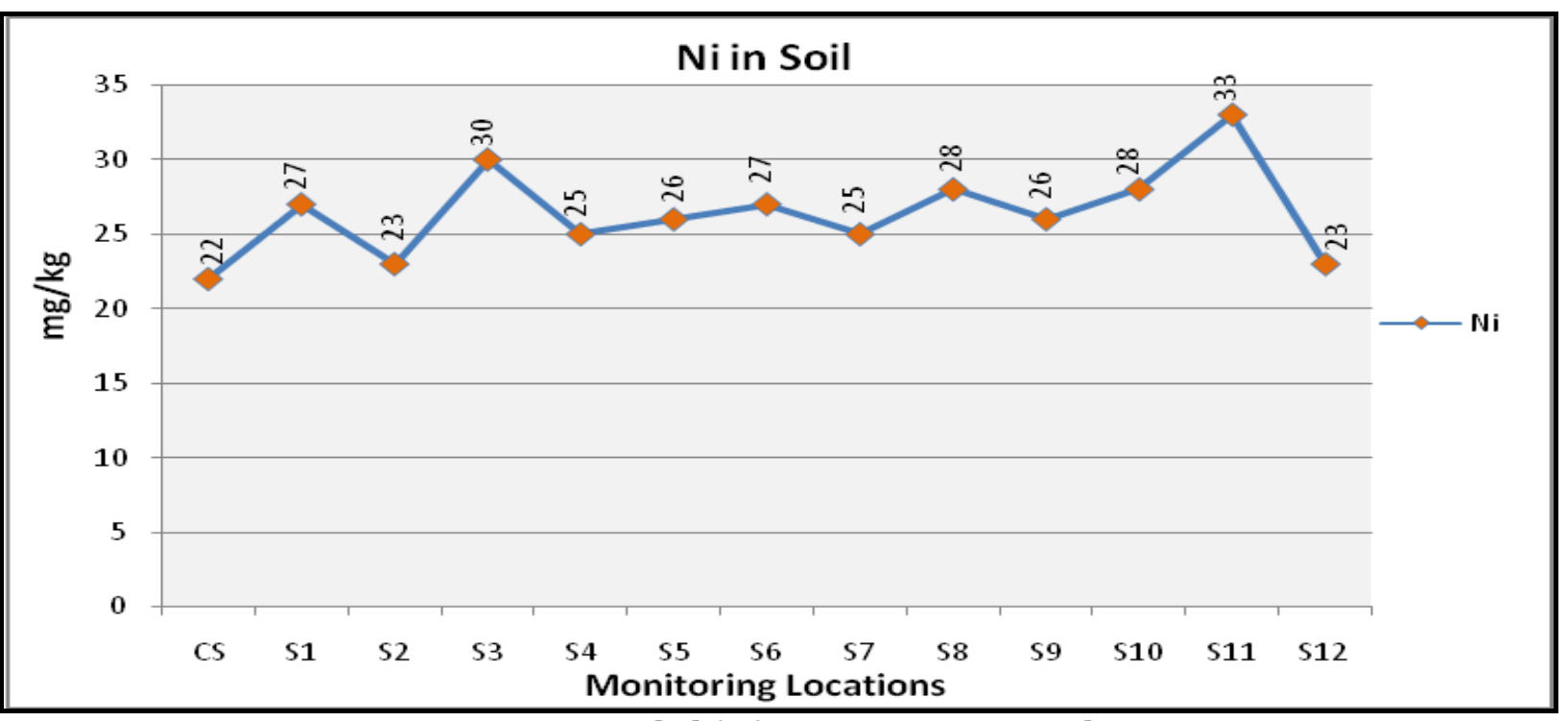

Figure 4: Nickel (Ni) concentration in Soil

Figure no 5 is showing that average concentration of copper $(\mathrm{Cu})$ was found $28 \mathrm{mg} / \mathrm{kg}$ at control site $(\mathrm{CS})$. Minimum average concentration was found 31 (S12) $\mathrm{mg} / \mathrm{kg}$ and maximum average concentration was found 266 (S2) $\mathrm{mg} / \mathrm{kg}$ during this study. 


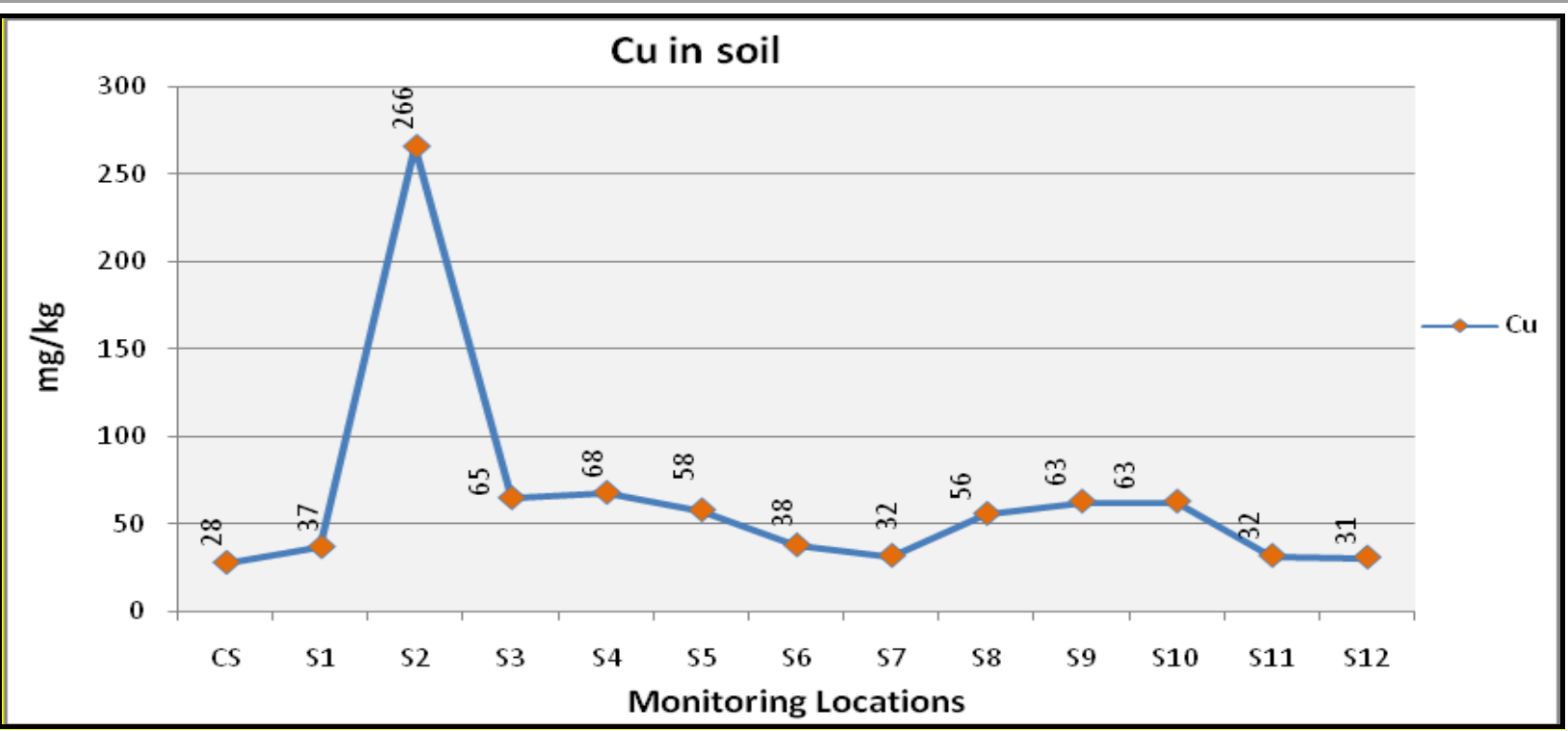

Figure 5: Copper (Cu) concentration in Soil

Figure no 6 is showing that average concentration of zinc ( $\mathrm{Zn}$ ) was found $56 \mathrm{mg} / \mathrm{kg}$ at control site (CS). Minimum average concentration was found 50 (S8) $\mathrm{mg} / \mathrm{kg}$ and maximum average concentration was found 93 (S1) $\mathrm{mg} / \mathrm{kg}$ during this study.

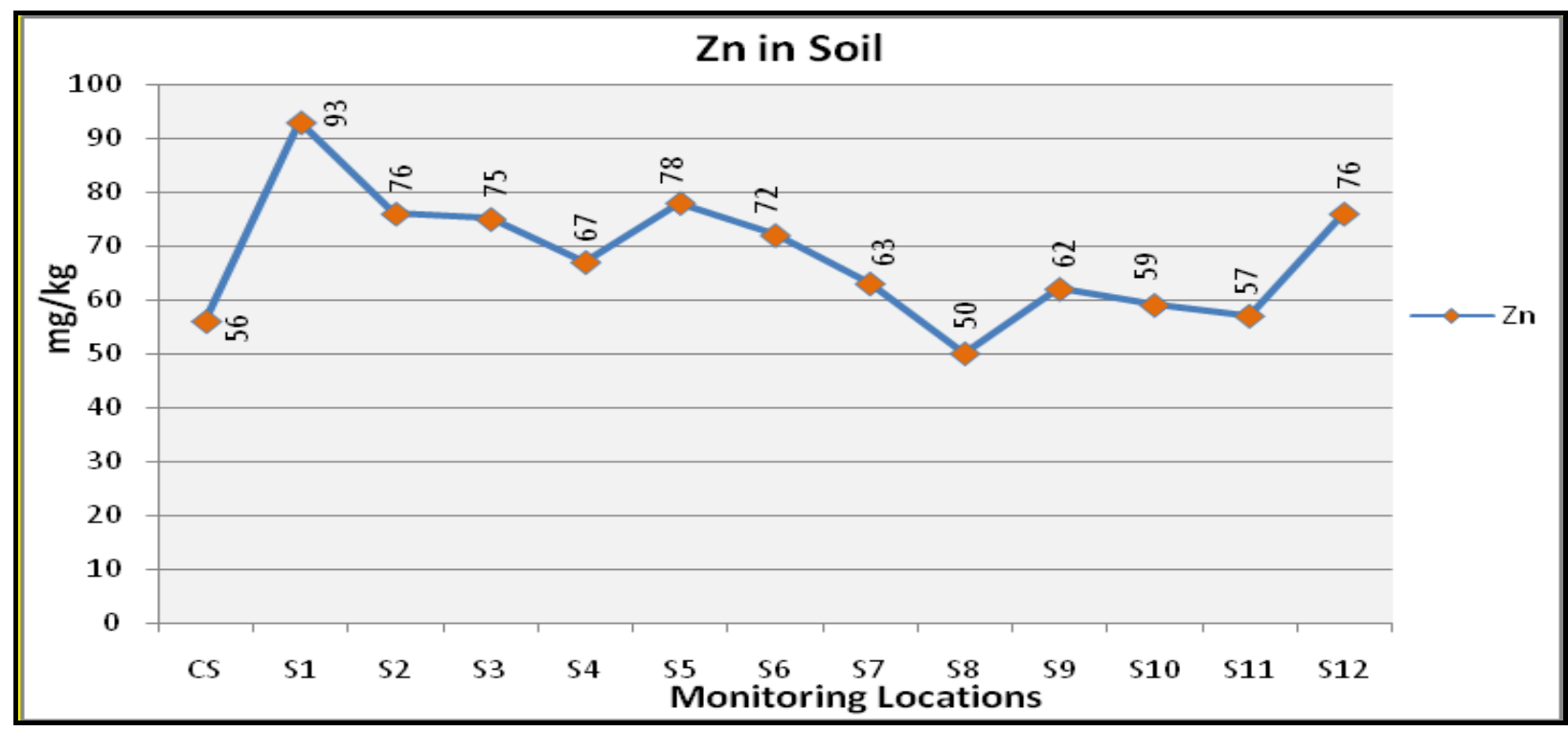

Figure 6: Zinc (Zn) concentration in Soil

Figure no 7 is showing that average concentration of Cobalt (Co) was found $16 \mathrm{mg} / \mathrm{kg}$ at control site (CS). Minimum average concentration was found 23 (S2 \&
$\mathrm{S} 12) \mathrm{mg} / \mathrm{kg}$ and maximum average concentration was found 29 (S1) $\mathrm{mg} / \mathrm{kg}$ during this study. 


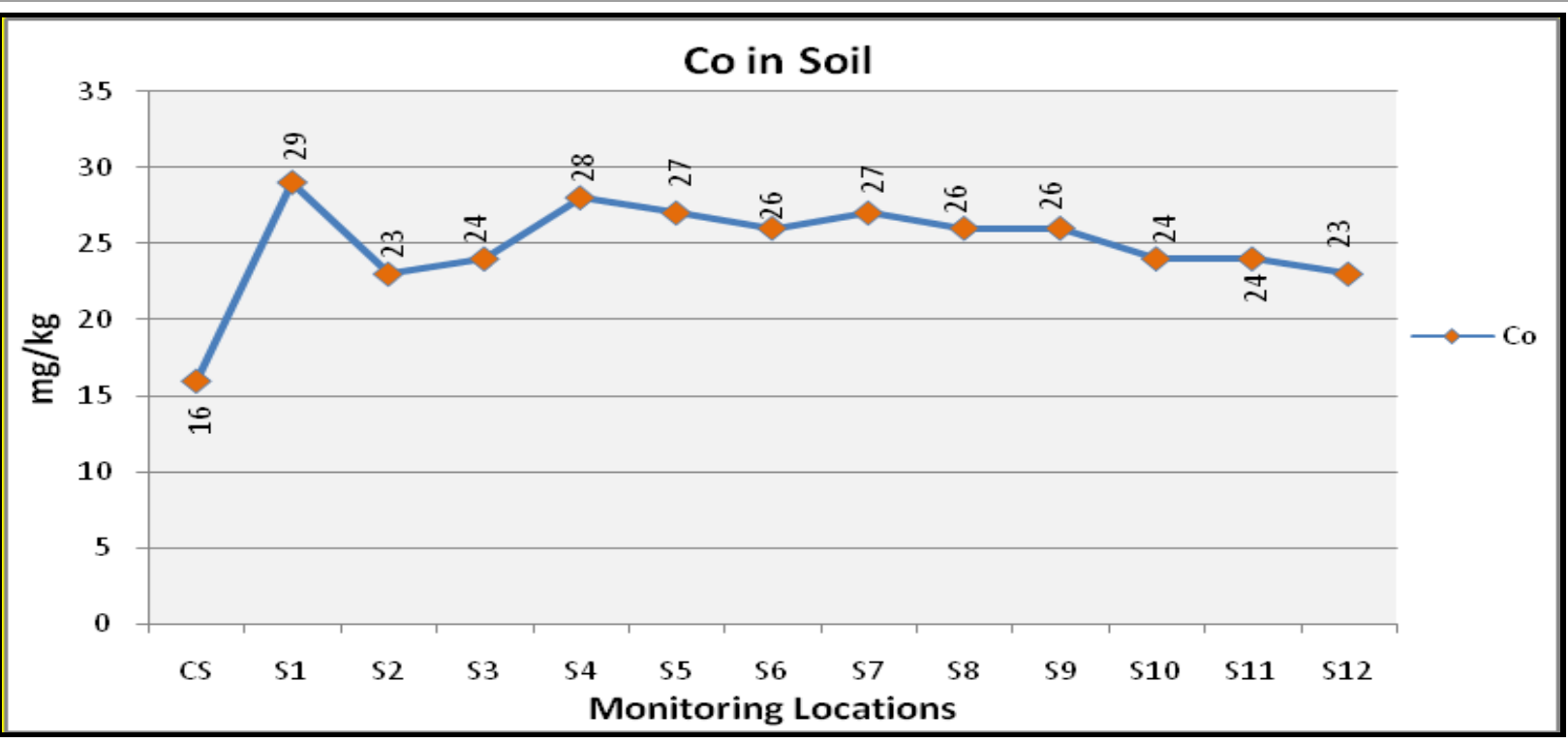

Figure 7: Cobalt (Co) concentration in Soil

Figure no 8 is showing that average concentration of cadmium (Cd) was found $2 \mathrm{mg} / \mathrm{kg}$ at control site (CS). Minimum average concentration was found 2 (S2, S3,
S6, S7, S9 \& S10) $\mathrm{mg} / \mathrm{kg}$ and maximum average concentration was found $8(\mathrm{~S} 12) \mathrm{mg} / \mathrm{kg}$ during this study.

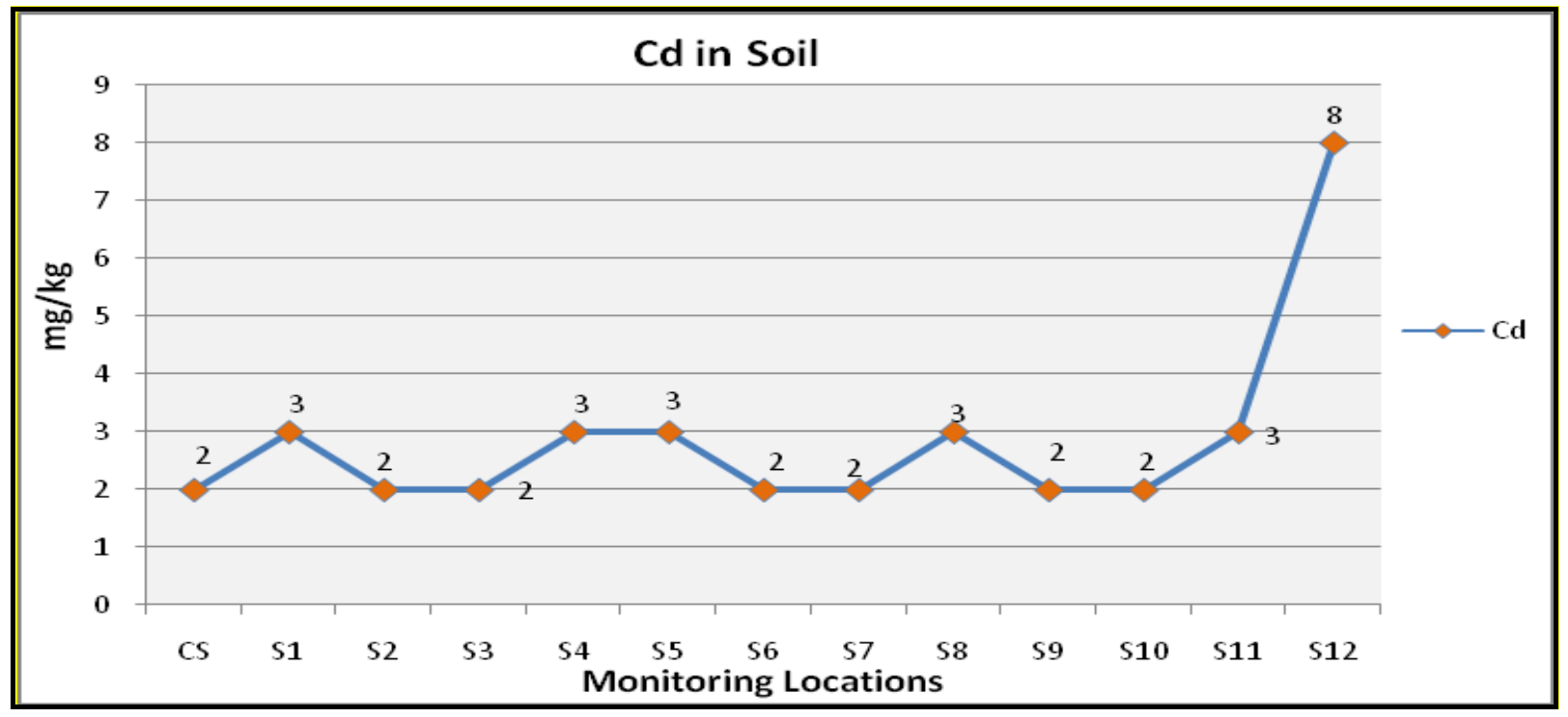

Figure 8: Cadmium (Cd) concentration in Soil

Figure no 9 is showing that average concentration of iron (Fe) was found $2077 \mathrm{mg} / \mathrm{kg}$ (CS) at control site. Minimum average concentration was found 4994 (S12) $\mathrm{mg} / \mathrm{kg}$ and maximum average concentration was found 11867 (S1) $\mathrm{mg} / \mathrm{kg}$ during this study. 


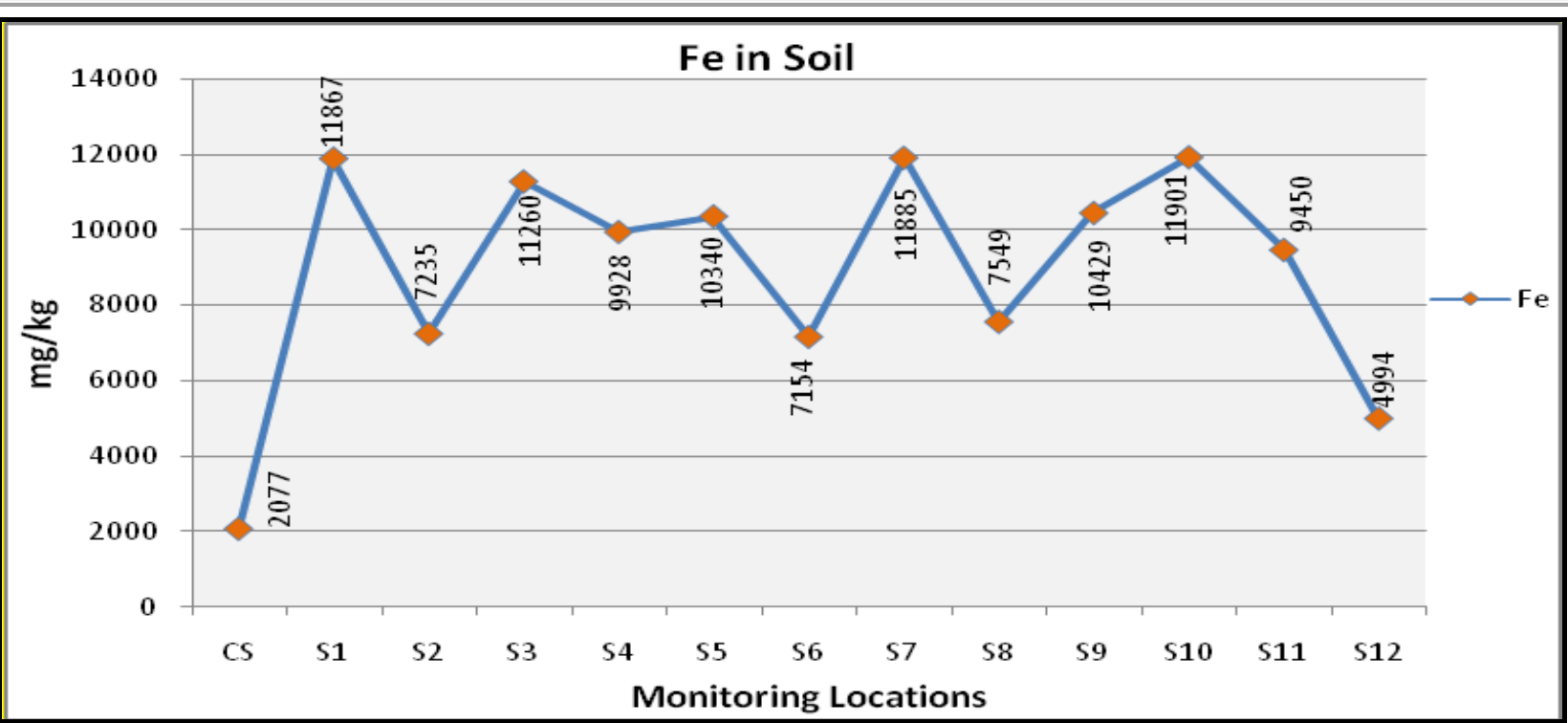

Figure 9: Iron (Fe) concentration in Soil

Figure no 10 is showing that average concentration of lead $(\mathrm{Pb})$ was found $11 \mathrm{mg} / \mathrm{kg}$ at control site $(\mathrm{CS})$. Minimum average concentration was found 11 (S12) $\mathrm{mg} / \mathrm{kg}$ and maximum average concentration was found 26 (S11) $\mathrm{mg} / \mathrm{kg}$ during this study.

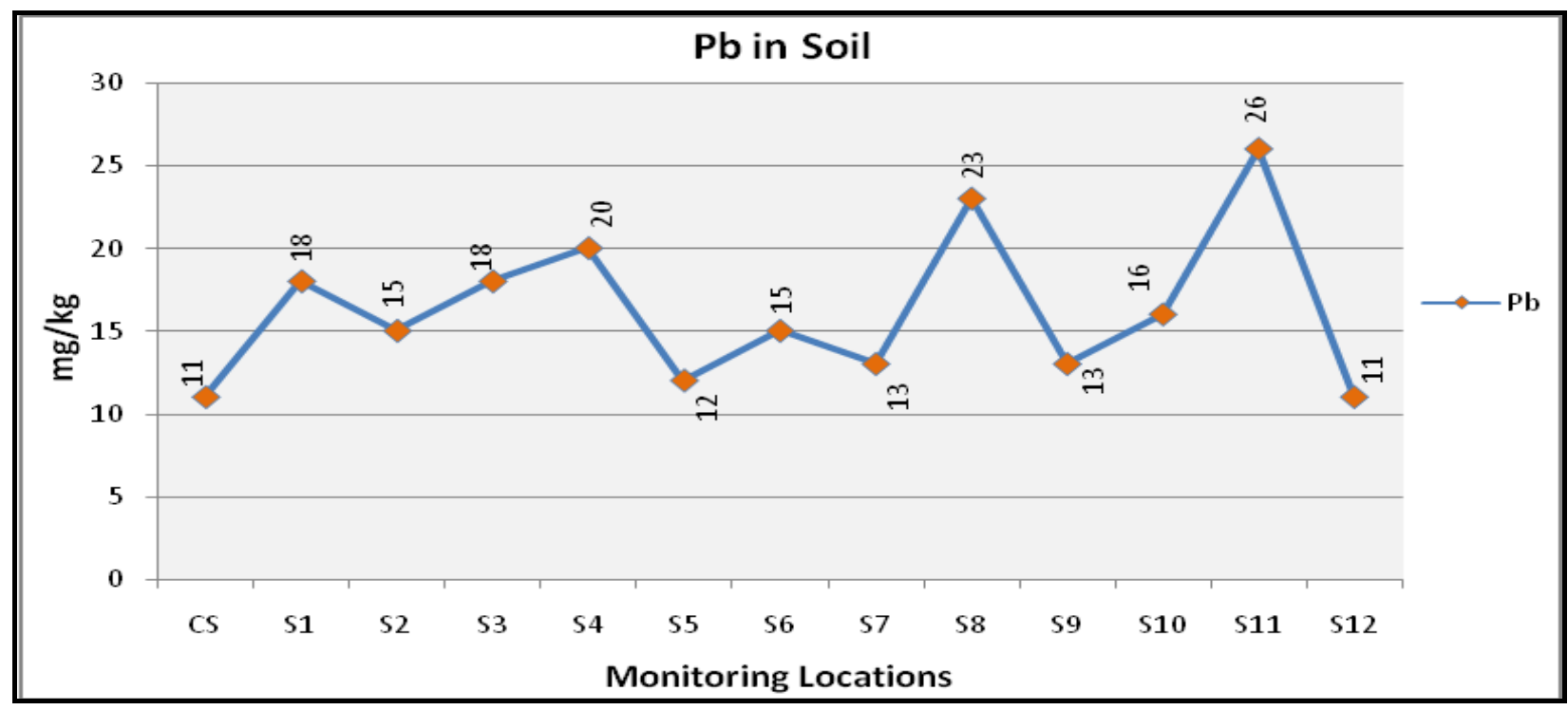

Figure 10: Lead $(\mathrm{Pb})$ concentration in Soil

Figure no 11 is showing that minimum Pollution Load Index was found 1.385 (S7) and maximum Pollution Load Index was found $1.807(\mathrm{~S} 1)$. Over all Pollution
Load Index was found greater than 1 which show polluted soil w.r.t. heavy metals under study at all selected monitoring locations during this study. 


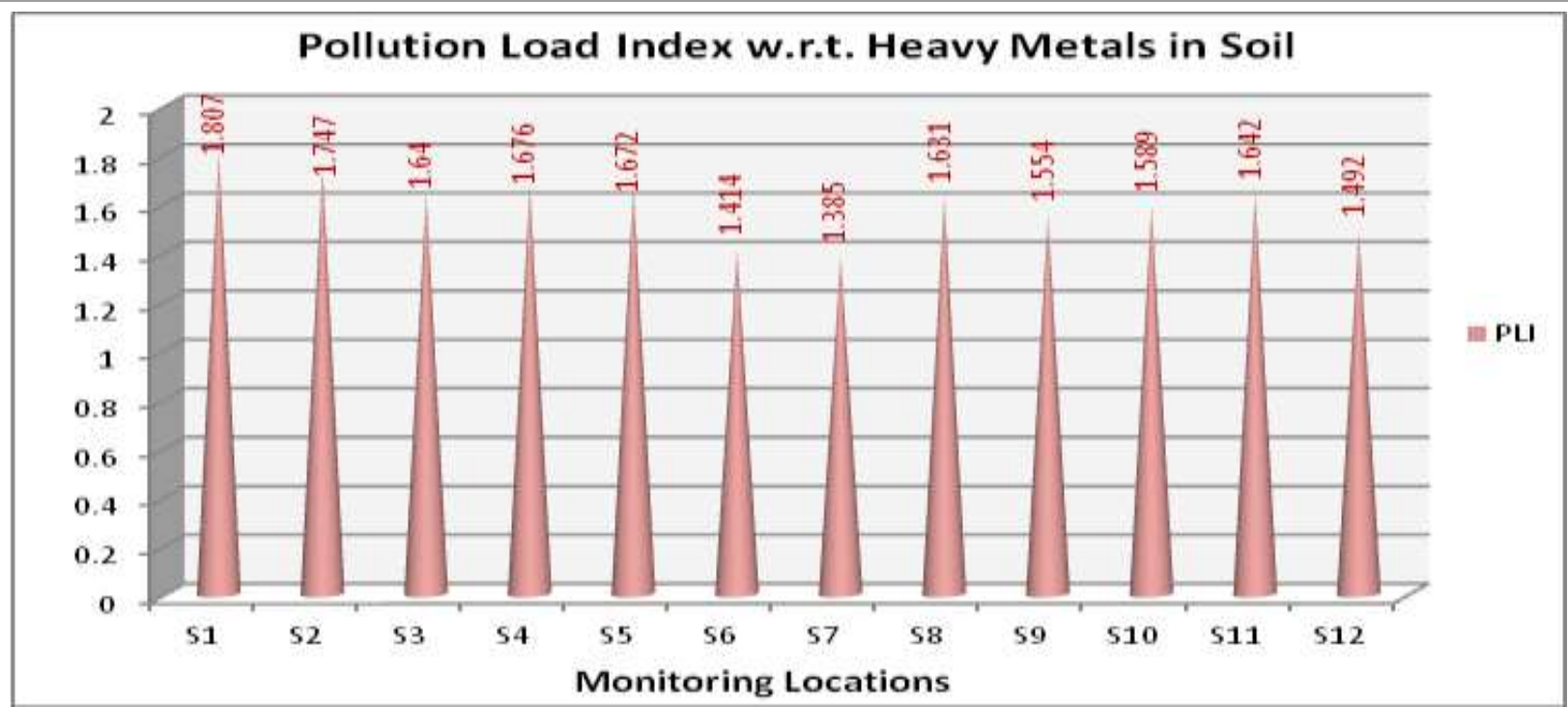

Figure 11: Pollution Load Index w.r.t. Heavy Metals in Soil

\section{CONCLUSION}

Mandideep is fast developing industrial area near Bhopal, the capital of Madhya Pradesh. The present study is an attempt to visualize the heavy metal contamination with w.r.t. Contamination Index (CI), Pollution Load Index (PLI) study at selected locations in Mandideep industrial area. Over all Pollution Load Index of soil was found greater than 1 which shows polluted soil w.r.t. heavy metals under study at all selected monitoring locations in Mandideep industrial area of Madhya Pradesh, India during this study.

\section{REFERENCES}

1. Weissmannová HD, Jiř́ Pavlovský J. (2017). Indices of soil contamination by heavy metals methodology of calculation for pollution assessment (minireview). Environ Monit Assess 189:616.

2. Lim H S, Lee J S, Chon H T, Sager M. (2008). Heavy metal contamination and health risk assessment in the vicinity of the abandoned Songcheon $A u-A g$ mine in Korea. Journal of Geochemical Exploration. 96 (2-3), 223-230.

3. Ji Y, Feng Y, Wu J, Zhu T, Bai Z, \& Duan C. (2008). Using geoaccumulation index to study source profiles of soil dust in China. Journal of Environmental Sciences. 20 (5), 571-578.

4. Varrica D, Tamburo E, Milia $N$, Vallascas E, Cortimiglia V, De Giudici G, Dongarrà G, Sanna E, Monna F, Losno R. (2014). Metals and metalloids in hair samples of children living near the abandoned mine sites of Sulcis-Inglesiente (Sardinia, Italy). Environmental Research, 134(Supplement C), 366-374.

5. Cai C, Xiong B, Zhang Y, Li X, Nunes ML. (2015). Critical Comparison of Soil Pollution Indices for
Assessing Contamination with Toxic Metals. Water Air Soil Pollut. 226: 352.

6. Wong SC, Li XD, Zhang G, Qi SH, Min YS. (2002). Heavy metals in agricultural soils of the Pearl River Delta, South China. Environ Pollut. 119(1): 33-44.

7. Cheng S. (2003). Heavy metal pollution in China: origin, pattern and control. Environ Sci Pollut Res Int. 10(3): 192-8.

8. Sajadi SA, Bazrafshan E, Jamali-Behnam F, Zarei A, Biglari H. (2015). Survey on the geostatistical distribution of heavy metals concentration in Sistan and Baluchistan's groundwater via geographic information system, Iran. Iran J Health Sci. 3(3): 18.

9. Mahmoudabadi E, Sarmadian F, \& Nazary Moghaddam R. (2015). Spatial distribution of soil heavy metals in different land uses of an industrial area of Tehran (Iran). International Journal of Environmental Science and Technology. 12, 32833298.

10. Ripin S N M, Hasan S, Kamal M L, \& Hashim N M. (2014). Analysis and pollution assessment of heavy metal in soil, Perlis. The Malaysian Journal of Analytical Sciences. 18, 155-161.

11. Mazurek R, Kowalska J, Ga siorek M, Zadrozny P, Jo 'zefowska A and Zaleski T. (2017). Assessment of heavy metals contamination in surface layers of Roztocze National Park forest soils (SE Poland) by indices of pollution. Chemosphere. 168, 839-850.

12. Liu R, Wang M, Chen W, \& Peng C. (2016). Spatial pattern of heavy metals accumulation risk in urban soils of Beijing and its influencing factors. Environmental Pollution. 210, 174-181.

13. Chahal V, Chand P, Nagpal A, Katnoria J K and Pakade YB. (2014) Evaluation of Heavy Metals Contamination and its Genotoxicity in Agricultural Soil of Amritsar, Punjab, India. Pakade et al. Int J Res Chem Environ. 4(4), 20-28. 
14. Acid Digestion of Sediments, Sludges and Soils, EPA Method 3050B, Revision 2 December 1996.

15. Lacutusu R. Appraising levels of soil contamination and pollution with heavy metals In Heinike HJ, Eckselman W, Thomasson AJ, et al. (2000) Land information systems for planning the sustainable use of land resources. European Soil Bureau Research Report No. 4. Office of Official Publication of the European Communities, Luxembourg. 393-402.

16. Hakanson L. (1980) An ecological risk index for aquatic pollution control: a sedimentological approach. Water Res. 14:975-1001.

17. Thomilson DC, Wilson DJ, Harris CR, et al. (1980). Problem in heavy metals in estuaries and the formation of pollution index. Helgol Mar Res. 33: 566-575.

18. Chakravarty $M$ and Patgiri AD (2009) Metal pollution assessment in sediments of the Dikrong river, N.E. India. J Hum Ecol. 27(1):63-67.

19. Cabrera F, Clemente L and Barrientos DE. (1999) Heavy metal pollution of soils affected by the Guadiamar toxic flood. Sci Total Environ . 242(13):117-129. 